\title{
Dosimetry of in vitro and in vivo Trials in Thermal Column Kartini Reactor for Boron Neutron Capture Therapy (BNCT) facility by using MCNPX Simulator Code
}

\author{
Adrian Tesalonika ${ }^{1,1}$, Andang Widi Harto², Yohannes Sardjono ${ }^{3}$, Isman Mulyadi Triatmoko ${ }^{4}$ \\ 1,2 Department of Physics Engineering, Faculty of Engineering, Universitas Gadjah Mada \\ Jalan Grafika 2 Yogyakarta 55281 Indonesia \\ 1adrian.tesalonika@mail.ugm.ac.id \\ ²andang@ugm.ac.id \\ ${ }^{3,4}$ Indonesian Nuclear Energy Agency (BATAN) \\ Jalan Babarsari no 21 Kotak Pos 6101 ykbb Yogyakarta, 55281, Indonesia \\ ssardjono.batan@gmail.com
}

Received: 15 September 2015, Revised: 30 February 2016, Accepted: 26 August 2016

\begin{abstract}
A dosimetry study of in vitro and in vivo trials system in thermal column of Kartini Reactor for Boron Neutron Capture Therapy (BNCT) facility has been conducted by using the Monte Carlo N-Particle Extended (MCNPX) software. Source of neutron originated from the $100 \mathrm{~kW}$ reactor which has been modified by the previous researcher. Models have been made by using simple geometries to represent tissues. Models of in vitro have been made by 4 spheres each has $1 \mathrm{~cm}$ diameter to represent tumour, whereas in vivo by 4 cylinders each has $6 \mathrm{~cm}$ length, $3 \mathrm{~cm}$ diameter, and breast soft tissue material with $1 \mathrm{~cm}$ sphere each located in the center of the cylinders to represent models of mouse with tumour. An increase in value of the boron concentration will increase the value of dose rate as well, then the exposure time should be shorter. The exposure times (in minutes) of in vitro trials for 20, 25, 30, 50, 75, 100, 125 , and $150 \mu \mathrm{g}$ boron/g tissues are 117.77, 117.77, 117.07, 115.69, 114.02, 112.39, 110.80, and 109.27. Whereas the exposure times of in vivo trials are $163.58,162.78,161.98,158.88,155.16,151.61,148.22$, dan 144.98. In vitro trials have greater values of dose rate so that in vitro trials have shorter exposure time.
\end{abstract}

Keywords: BNCT, in vitro, in vivo, dosimetry, exposure time

\section{INTRODUCTION}

Radiation is emission of energy. There are two types of radiation, ionizing radiation and non-ionizing radiation. Ionizing radiation is radiation which can ionize atoms or molecules around its path of radiation. Non-ionizing radiation can not ionize atoms or molecules around its path. Non-ionizing radiation has a wave length of $10 \mathrm{~nm}$ or more, examples of this type of radiation are radio wave, micro wave, visible light, and ultraviolet light. Ionizing radiation has a wave length of less than $10 \mathrm{~nm}$, examples are X-ray and gamma ray (Nicholas Tsoulfanidis, 1995).
Cancer is a special name of an illness which can attack all of body parts. Another name for it is maligna tumour and neoplasmm. One of the properties it has is to produce abnormal cells rapidly which grow more than they should, and can invade another organs, the process is called metastasis. Metastasis is the main problem that can cause death in cancer (World Health Organization, 2015).

Cancer is one of the reasons that cause illnesses and deaths around the world, to be exact four million new cases and 8.2 millions of deaths are because of cancer in year 2012 . New case is predicted can increase up to

${ }^{1}$ Adrian Tesalonika. Email: adrian.tesalonika@mail.ugm.ac.id 
seventy percents in the last two decades (World Health Organization, 2015). Based on the data of GLOBOCAN 2012 (globocan.iarc.fr) the number of cases in Indonesia is up to 300.000 cases, with is lead by breast cancer which is up to fifty thousands cases.

Based on the data, a judgement is made to destroy cancer cells as fast as possible before they spread to other normal cells. There are three methods to treat cancer, by operation, radiotherapy, and sistemic therapy. (World Health Organization, 2015).

Radiation used for therapy or medication is named radiotherapy. This radiation works by damaging the cells' DNA. The gens in cells are managing the growth and cells reproduction. When radiation damages cells' DNA, the cells will die (American Cancer Society, 2014). Radiotherapy is usually done with X-ray, gamma ray, or another charged particle. It uses high energy and can be dangerous to normal cells around the target, and those methods are not effective because they have low Linear Energy Transfer (LET). (Nina Fauziah, 2013) (Herman Cember \& Tomas E. Johnson, 2009)

BNCT is a technique for cancer therapy designed to reach target selectively. It was introduced by G. L. Locher in 1936 shortly after the neutron had been introduced by Chadwick in 1932 and the reaction of ${ }^{10} \mathrm{~B}(\mathrm{n}, \alpha)^{7} \mathrm{Li}$ had been descripted by Taylor and Goldhaber in 1935. (D. Rorer, et al., 2001)

BNCT is using Boron-10 nuclide which is a non-radioactive material to absorb thermal neutrons then produce a nuclear reaction of ${ }^{10} \mathrm{~B}(\mathrm{n}, \alpha){ }^{7} \mathrm{Li}$. Result of this reaction is a product that has high LET. The range of this product in water or in soft tissue is between 4.5 to 10 $\mu \mathrm{m}$, so then the energy is inside of the cell. Based on this theory, there is a possibility to selectively radiate the tumour cells which has been given Boron-10 and avoid normal cells.
The base of this nuclear reaction is as follows (W. A. G. Sauerwein, A. Wittig, R. Moss, \& Y. Nakagawa, 2012)

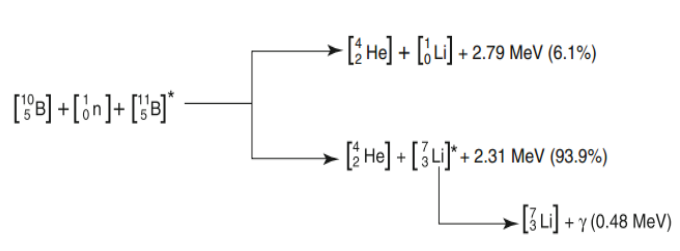

Neutron source was from Kartini Reactor after passed the collimator which has been modified by Ranti Warfi (Ranti Warf, 2015). Neutron properties from the thermal column collimator is shown in Table 1.

Table 1.Collimator Design Specification by Ranti Warfi (Ranti Warfi, 2015)

\begin{tabular}{ccc}
\hline Category & Optimized & $\begin{array}{c}\text { Design } \\
\text { Requirements } \\
\text { (IAEA) }\end{array}$ \\
\hline$\Phi_{\text {epi }}\left(\mathrm{n} \cdot \mathrm{cm}^{-2} \cdot \mathrm{s}^{-1}\right)$ & $1.13 \mathrm{E} 09$ & $>1.00 \mathrm{E} 09$ \\
$\square_{\mathrm{f}} / \Phi_{\text {epi }}\left(\mathrm{Gy} \cdot \mathrm{cm}^{2} \cdot \mathrm{n}^{-1}\right)$ & $1.76 \mathrm{E}-13$ & $<2.00 \mathrm{E}-13$ \\
$\square_{\gamma} / \Phi_{\text {epi }}\left(\mathrm{Gy} \cdot \mathrm{cm}^{2} \cdot \mathrm{n}^{-1}\right)$ & $1.45 \mathrm{E}-13$ & $<2.00 \mathrm{E}-13$ \\
$\Phi_{\text {th }} / \Phi_{\text {epi }}$ & $1.08 \mathrm{E}-02$ & $<0.05$ \\
$\mathrm{~J} / \Phi_{\text {total }}$ & 0.705 & $>0.7$ \\
\hline
\end{tabular}

Standard output value from the collimator is needed to determine the quality of the design that has been made. The standard is settled by International Atomic Energy Agency (IAEA). Parameters in Table 1 has full filled the standard recommendation from IAEA.

Breast cancer is malignant tumour which started in breast cells. In 1990, was predicted that $59 \%$ of the cases are in the more developed countries (like North America, Europe, Australia, New Zealand, and Japan), although these areas had less than one fourth of the global female population at that time. The situation has changed after two decades; in 2008, the number of new diagnosed has been divided between more developed countries and less developed countries, and in 2012 was predicted that the majority (53\%) from the female breast cancer cases are in the less 
developed countries. In Indonesia, there are about fifty thousand cases based on the GLOBOCAN data 2012 (Ferlay J, et al., 2013). Besides that, data from registration of Jakarta Cancer shows that ten biggest cancer category especially for female at year 2005-2007 are breast cancer (18.6 cases within 100,000 population), cervical cancer ( 9.25 within 100,000$)$, ovarian cancer (4.27 within $100,000)$, colorectal cancer ( 3.15 within 100,000$)$, bronchial and lung cancer (2.4 within 100,000), thyroid cancer (2.21 within 100,000), uterine corpus cancer (1.76 within 100,000), pharyngeal cancer (1.72 within 100,000), leukemia (1.61 within 100,000$)$, and liver cancer (1.41 within 100,000) (Mugi Wahidin, et al., 2012). From the data, the case that happens most of the time is breast cancer, then this research will be focused at the breast cancer.

According to the results in Table 1, the research of in vitro and in vivo trials simulations for BNCT at breast cancer on mouse models by using MCNPX software will be conducted. Neutron source was from the thermal column collimator of Kartini Reactor which has been modified in the previous research by Ranti Warfi. Targets are modeled in MCNPX.

\section{MATERIALS AND METHODS Modeling}

In vitro is Latin for "in glass"; (Of a process) performed or taking place in a test tube, culture dish, or elsewhere outside a living organism (Oxford Dictionaries, n.d.). The models have been done by modeling the shape of tumour which has a spherical geometry with one centimeter diameter. Four spherical geometries with different positions represented four tumours which each had been taken from the mouse model for the trials.

In vivo is Latin for "in a living organism"; (Of processes) performed or taking place in a living organism (Oxford Dictionaries, n.d.).
Mouse model was used in this research. The modeling has been done by modeling the mice into a simple cylindrical geometry with a spherical tumour inside the cylinder.

\section{Monte Carlo Method}

Monte Carlo method uses a probabilistic method to examine the interaction that would occur in a radiation (Andang Widi Harto). This method determines the desired value by recording a simulation of each movement and properties of the particles and the medium in their path. Monte Carlo method is used in the Monte Carlo N Particle Extended (MCNPX) software. MCNPX only displays information in accordance with the desired tally input by users (Denise B. Pelowitz, 2008) (M.Ilma Muslih Arrozaqi, 2014).

Sampling of statistics on MCNP based on random selection.Distribution probability using the transport data to determine the output or result of each particle.

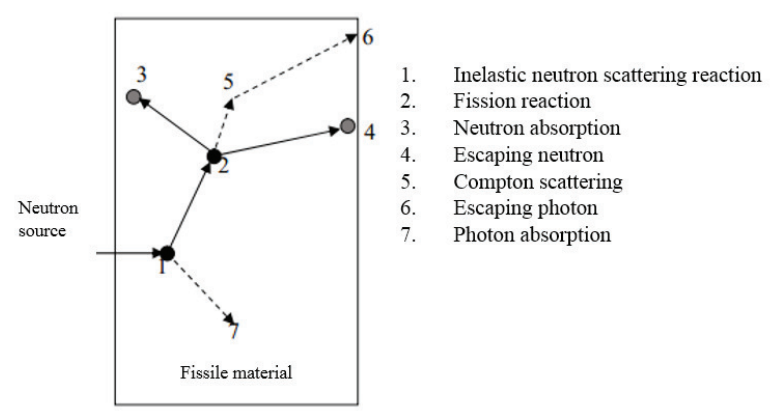

Figure 1. Trackrecord illustration of particles in MCNP(Bambang Hadi Santoso, 2014)

The picture above shows the traces of the interactions of neutrons in a thin board. Neutron interactions with matter become the doses components which later will be calculated. These components include recoil and photon radiation. Results of interactions are quite diverse and have varying energy and some radioactive. The halflife and activity of the recoil become important to consider in utilization. 
Cell card is the part that contains the volume unit that has been assembled from the surface card and filled by material from the data card (M.Ilma Muslih Arrozaqi, 2014). Every cell card is described by a cell number, a material number, a material density and follows by surface card numbers which limit the volume of a cell. In the code of material density while using a positive operator, it has a meaning of the atom density, whereas a negative operator, it has a meaning of the compound density. Material number and density can be changed with 0 (zero) to define a void cell (empty cell). In the code section of surface number, negative and positive operator are used, positive defines if cell is on the right/top of the surface, whereas negative if cell is on the left/bottom of the surface.

Surface card defines the limits of a standard geometry which is an expression of a mathematical equation (M.Ilma Muslih Arrozaqi, 2014). Surface card is defined by using coefficients of analytical surface equation or for specifics surface, it is known by the points in the surface equation (Irhas, 2014).

Data card contains information about volume unit, it can be elements of volume unit composition, radiation source, data point interpolation for radiation dose, measurement mode, energy, and the amount of iteration which will be done depends on how much of the accuracy needed (M.Ilma Muslih Arrozaqi, 2014). In this research, used parts of data card are: mode card, nps, and tally.

Tally is used when the user wants to collect data from the MCNP calculation. Collectable data are the flux in a certain cell, the current over a surface, the flux at a certain point, etc.

Information can be collected by using tally codes as follows.

Table 2. MCNP Geometry Codes Used in This Research

\begin{tabular}{|c|c|c|c|c|}
\hline Symbol & Type & Description & Equation & Card Entries \\
\hline $\mathrm{P}$ & \multirow{4}{*}{ Plane } & General & $A x+B y+C z-D=0$ & $\mathrm{ABCD}$ \\
\hline PX & & Normal to $\mathrm{x}$-axis & $x-D=0$ & $\mathrm{D}$ \\
\hline PY & & Normal to y-axis & $y-D=0$ & $\mathrm{D}$ \\
\hline $\mathrm{PZ}$ & & Normal to z-axis & $z-D=0$ & $\mathrm{D}$ \\
\hline SO & \multirow[t]{2}{*}{ Sphere } & Centered at origin & $x^{2}+y^{2}+z^{2}-R^{2}=0$ & $\mathrm{R}$ \\
\hline $\mathrm{S}$ & & General & $(x-\bar{x})^{2}+(y-\bar{y})^{2}+(z-\bar{z})^{2}-R^{2}=0$ & $\bar{x} \overline{y z} R$ \\
\hline $\mathrm{C} / \mathrm{X}$ & \multirow{4}{*}{ Cylinder } & Parallel to $\mathrm{x}$-axis & $(y-\bar{y})^{2}+(z-\bar{z})^{2}-R^{2}=0$ & $\bar{y} \bar{z} R$ \\
\hline $\mathrm{C} / \mathrm{Y}$ & & Parallel to $y$-axis & $(x-\bar{x})^{2}+(z-\bar{z})^{2}-R^{2}=0$ & $\bar{x} \bar{z} R$ \\
\hline $\mathrm{C} / \mathrm{Z}$ & & Parallel to z-axis & $(x-\bar{x})^{2}+(y-\bar{y})^{2}-R^{2}=0$ & $\bar{x} \bar{y} R$ \\
\hline $\mathrm{CX}$ & & On $\mathrm{x}$-axis & $y^{2}+z^{2}-R^{2}=0$ & $\mathrm{R}$ \\
\hline $\mathrm{CY}$ & \multirow[t]{2}{*}{ Cylinder } & On y-axis & $x^{2}+z^{2}-R^{2}=0$ & $\mathrm{R}$ \\
\hline $\mathrm{CZ}$ & & On z-axis & $x^{2}+y^{2}-R^{2}=0$ & $\mathrm{R}$ \\
\hline
\end{tabular}


Adrian Tesalonika, Andang Widi Harto, Yohannes Sardjono, Isman Mulyadi Triatmoko, Dosimetry of in Vitro and in Vivo Trials in Thermal Column Kartini Reactor for Boron Neutron Capture Therapy (BNCT) Facility by Using MCNPX Simulator Code

Table 3.MCNP Tally Code

\begin{tabular}{|c|c|c|c|}
\hline Tally & $\begin{array}{l}\text { Particle } \\
\text { Mode }\end{array}$ & Description & Units \\
\hline F1 & $: \mathrm{N},: \mathrm{P},: \mathrm{E}$ & $\begin{array}{c}\text { Current integrated } \\
\text { over a surface }\end{array}$ & particles \\
\hline F2 & $: \mathrm{N},: \mathrm{P}, \mathrm{E}$ & $\begin{array}{c}\text { Flux average over a } \\
\text { surface }\end{array}$ & $\begin{array}{c}\text { particles/ } \\
\mathrm{cm}^{2}\end{array}$ \\
\hline F4 & $: \mathrm{N},: \mathrm{P}, \mathrm{E}$ & $\begin{array}{c}\text { Flux average over a } \\
\text { cell }\end{array}$ & $\begin{array}{c}\text { particles/ } \\
\mathrm{cm}^{2}\end{array}$ \\
\hline F5a & $: \mathrm{N},: \mathrm{P}$ & $\begin{array}{c}\text { Flux at a point or ring } \\
\text { detector }\end{array}$ & $\begin{array}{c}\text { particles/ } \\
\mathrm{cm}^{2}\end{array}$ \\
\hline F6 & $\begin{array}{l}: N,: P \\
: N, P\end{array}$ & $\begin{array}{l}\text { Energy deposition } \\
\text { averaged over a cell } \\
\text { Fission energy }\end{array}$ & $\mathrm{MeV} / \mathrm{g}$ \\
\hline F7 & $: \mathrm{N}$ & $\begin{array}{c}\text { deposition averaged } \\
\text { over a cell }\end{array}$ & $\mathrm{MeV} / \mathrm{g}$ \\
\hline F8 & $\begin{array}{l}: \mathrm{N},: \mathrm{P},: \mathrm{E} \\
\quad: \mathrm{P}, \mathrm{E}\end{array}$ & $\begin{array}{l}\text { Energy distribution } \\
\text { of pulses created in a } \\
\text { detector by radiation }\end{array}$ & pulses \\
\hline
\end{tabular}

MCNPX has material card which contains data of cell card's components. In the material card, mass fraction of tumor components and other tissues are written. Mass fraction of the tissue components are important because every element has a different value of neutron cross section. The differences will vary the probability of neutron interaction which go through the tissue, then the dose will vary as well.

Table 4. Tumour Main Components

\begin{tabular}{ccccc}
\hline $\begin{array}{c}\text { Atomic } \\
\text { Number }\end{array}$ & $\begin{array}{c}\text { Mass } \\
\text { Number }\end{array}$ & $\begin{array}{c}\text { MCNP } \\
\text { code }\end{array}$ & Element & Wt \\
\hline 1 & 1 & 1001 & $\mathrm{H}$ & 0.099 \\
6 & 12 & 6012 & $\mathrm{C}$ & 0.269 \\
7 & 14 & 7014 & $\mathrm{~N}$ & 0.045 \\
8 & 16 & 8016 & $\mathrm{O}$ & 0.569 \\
15 & 31 & 15031 & $\mathrm{P}$ & 0.018 \\
\hline
\end{tabular}

Table 5. Breast Tissue Main Components

\begin{tabular}{ccccc}
\hline $\begin{array}{c}\text { Atomic } \\
\text { Number }\end{array}$ & $\begin{array}{c}\text { Mass } \\
\text { Number }\end{array}$ & $\begin{array}{c}\text { MCNP } \\
\text { code }\end{array}$ & Element & Wt \\
\hline 1 & 1 & 1001 & $\mathrm{H}$ & 0.106000 \\
6 & 12 & 6012 & $\mathrm{C}$ & 0.332000 \\
7 & 14 & 7014 & $\mathrm{~N}$ & 0.030000 \\
8 & 16 & 8016 & $\mathrm{O}$ & 0.527000 \\
11 & 23 & 11023 & $\mathrm{Na}$ & 0.001000 \\
15 & 31 & 15031 & $\mathrm{P}$ & 0.001000 \\
16 & 32 & 16000 & $\mathrm{~S}$ & 0.002000 \\
17 & 34 & 17000 & $\mathrm{Cl}$ & 0.001000 \\
\hline
\end{tabular}

Some of the mass fraction in this research are from these elements: Nitrogen-14, Hydrogen-1, and Boron-10 in soft tissue. Their interaction produces the main dose components to be calculated in BNCT.

Some mass fraction of elements in soft tissue are as follows. (International Commission on Radiation Unit and Measurements, 1989)

\section{BNCT Dose}

In BNCT there are types of dose will be calculated to obtain total dose. They are as follows (D. Rorer, et al., 2001):

- LET proton dose

- Boron dose

- Gamma dose

- Neutron dose

\section{Proton Dose $\left({ }^{14} \mathrm{~N}(\mathrm{n}, \mathrm{p}){ }^{14} \mathrm{C}\right.$ reaction)}

Proton dose originated from the neutron captured by Nitrogen-14 interaction. This interaction produces Carbon-14 and $0.66 \mathrm{MeV}$ energy proton. The dose rate can be calculated by using the equation:

$$
\begin{aligned}
& \dot{D}_{p}=\frac{\emptyset N_{N} \sigma_{N} Q \times 1,6 \times 10^{-13} \mathrm{~J} / \mathrm{MeV}}{1 \frac{\mathrm{J} / \mathrm{kg}}{G y}} \\
& \text { Information: } \\
& \dot{\mathrm{D}}_{\mathrm{p}}=\text { proton dose rate }(\mathrm{Gy} / \mathrm{s})
\end{aligned}
$$

$$
\begin{aligned}
& \emptyset=\text { thermal neutron flux }\left(\mathrm{n} / \mathrm{cm}^{2} \mathrm{~s}\right) \\
& \begin{array}{r}
\mathrm{N}_{\mathrm{N}}=\text { amount of Nitrogen atoms/tissue weight (atom/ } \\
\mathrm{kg})
\end{array} \\
& \begin{array}{l}
\sigma_{\mathrm{N}}=\text { Nitrogen microscopic cross section }\left(\mathrm{cm}^{2}\right) \\
\mathrm{Q}=\text { particle energy }(\mathrm{MeV})
\end{array}
\end{aligned}
$$

\section{Boron Dose}

Boron dose originated from the thermal neutron captured by Boron-10 interaction. This 
interaction produces Lithium-7 and $2.33 \mathrm{MeV}$ energy alpha. Dose rate from this interaction can be calculated by using the equation:

$$
\dot{D_{B}}=\frac{\emptyset N_{B} \sigma_{B} Q \times 1,6 \times 10^{-13} \mathrm{~J} / \mathrm{MeV}}{1 \frac{\mathrm{J} / \mathrm{kg}}{G y}}
$$

Information:

$\dot{\mathrm{D}_{\mathrm{B}}}=$ alpha dose rate $(\mathrm{Gy} / \mathrm{s})$

$\emptyset=$ thermal neutron flux $\left(\mathrm{n} / \mathrm{cm}^{2} \mathrm{~s}\right)$

$\mathrm{N}_{\mathrm{B}}=$ amount of Boron atoms/tissue weight (atom $/ \mathrm{kg}$ )

$\sigma_{\mathrm{B}}=$ Boron microscopic cross section $\left(\mathrm{cm}^{2}\right)$

$\mathrm{Q}=$ particle energy $(\mathrm{MeV})$

\section{Gamma Dose}

Gamma dose is equal with the accumulation of thermal neutron captured by hydrogen reaction rate. Hydrogen in tissue will capture thermal neutron. This reaction rate is equal to form rate of Hydrogen-2. This form rate is equal to gamma emits rate with $2.23 \mathrm{MeV}$ energy. Hydrogen-2 is an exited atom.

$$
\dddot{R}=\emptyset N_{H} \sigma_{H}
$$

Information:

$\dddot{\mathrm{R}}$

$$
\begin{aligned}
\stackrel{\mathrm{R}}{=} & \text { Hydrogen }-2 \text { form rate } / \text { gamma emits } \\
& \text { rate(photon } / \mathrm{kg} \mathrm{s}=\mathrm{Bq} / \mathrm{kg}) \\
\emptyset= & \text { Thermal neutron flux }\left(\mathrm{n} / \mathrm{cm}^{2} \mathrm{~s}\right) \\
\mathrm{N}_{\mathrm{H}=} & \text { amount of Hydrogen atom } / \text { weight tissue(atom/ } \\
\sigma_{\mathrm{H}}= & \mathrm{kg})
\end{aligned}
$$

Gamma dose rate from Hydrogen reaction:

$$
\dot{D}_{\gamma}=\dddot{R} \times \varphi \times \Delta \frac{G y}{s}
$$

Information:

$\varphi=$ absorbed dose fraction of gamma.

$\Delta=$ absorbed dose rate coefficient / specific activity. $((\mathrm{Gy} / \mathrm{s}) /(\mathrm{Bq} / \mathrm{kg}))$ (Irhas, 2014) (Dwi Berlianti Siwi, 2013)

Absorbed dose rate of gamma is a coefficient that show dose in the tissue from the specific gamma radiation.

This calculation was done manually because MCNPX is just capable of dose and flux neutron neutron calculation and intensity which happened when irradiation. Gamma dose and dose from the neutron and matter interaction in tissue cannot be measured by MCNPX.

\section{Total Dose}

Total dose which absorbed in each tissue was calculated by timing each dose component with radiation weight factor. This calculation use the formula:

$D_{\text {total }}^{\cdot}=w_{B} \dot{D}_{B}+w_{p} \dot{D}_{p}+w_{n} \dot{D}_{n}+w_{\gamma} \dot{D}_{\gamma}$

Information:

$\mathrm{W}_{\mathrm{B}}=$ weight factor for alpha particles are 3.8 (tumour) and 1.35 (normal tissue).

$\mathrm{w}_{\mathrm{p}}=$ weight factor for proton is 3.2 .

$\mathrm{w}_{\mathrm{n}}=$ weight factor for neutron is 3.2

$\mathrm{w}_{\gamma}=$ weight factor for gamma is 1

Weight factor is the coefficient to show the damaging capability from an absorbed radiation. The value is different for each type of radiation and influenced by target tissue radio sensitivity (D. Rorer, et al., 2001). The value of weight factor above are obtained by the previous clinical trial of BPA compound.

$\Delta=1,6 \times 10^{-13} \times 2,23 \frac{\mathrm{MeV}}{\gamma}=3,568 \times 10^{-13} \frac{\mathrm{Gy} / \mathrm{s}}{\mathrm{Bq} / \mathrm{kg}}$ 
Adrian Tesalonika, Andang Widi Harto, Yohannes Sardjono, Isman Mulyadi Triatmoko, Dosimetry of in Vitro and in Vivo Trials in Thermal Column Kartini Reactor for Boron Neutron Capture Therapy (BNCT) Facility by Using MCNPX Simulator Code

\section{RESULTS AND DISCUSSION}

The boron concentration is varied in each simulation. The variations are $20,25,30,50,75$, 100,125 , and $150 \mu \mathrm{g}$ boron/g tissue.

Tumour in simulation for in vitro was modelled to a simple spherical geometry which has $1 \mathrm{~cm}$ diameter. This research has 4 of the spherical geometries to get the average values of them.

Mice in simulation for in vivo were modeled to simple cylindrical geometries and the tumour is modeled to a spherical geometry each were inside the cylinders.

The measurements were done to get data of thermal neutron flux, neutron scattering dose, and gamma scattering dose. After the data has been established, calculations were done in Excel to get the total dose and time of radiation.

Data after final calculation in Excel were done are at Table 6 and Table 2.

The tables and the graph show the irradiation time to reach the total dose of $50 \mathrm{~Gy}$ (total irradiation dose of breast cancer therapy). The time for in vitro are shorter than in vivo. This happens because in vitro dose rate is higher than in vivo dose rate.

\section{CONCLUSION AND REMARKS}

This research has produced several results.
First, the higher the boron concentration will result in higher dose rate. It then affected the irradiation time to reach total dose, so the irradiation time became quicker.

Second, the irradiation time (in minutes) in each variation of boron concentration $(20,25$, $30,50,75,100,125$, and $150 \mu \mathrm{g}$ boron/g tissue) for in vitro are 117.77, 117.77, 117.07, 115.69, $114.02,112.39,110.80$, and 109.27. The results for in vivo are 163.58, 162.78, 161.98, 158.88, $155.16,151.61,148.22$, and 144.98 .

\section{ACKNOWLEDGMENT}

The author wish to give a deeply gratitude for Dr. Ir. Andang Widi Harto, MT., Prof. Ir. Yohannes Sardjono, and Drs. Widarto for any instructions and guidance to write this paper. To Dr. Susilo Widodo, as Head of PSTA-BATAN, who had allowed the author conducted research in PSTA-BATAN. To Ranti Warfi, Martinus I Made Adrian, and all colleagues who conducted the research all together.

\section{POLICY BRIEF}

Another research to proof this concept of ideas and simulations is recommended due to increase the readiness of BNCT facility and technology in Indonesia. The number of cancer cases in Indonesia are surprisingly high and 67\% of them were lead to death. Therefore, BNCT are needed to minimize the cancer cases or at least to decrease the number of cancer deaths.

Table 6. In Vitro Measurements

\begin{tabular}{cccc}
\hline $\begin{array}{c}\text { Boron Concentration } \\
(\boldsymbol{\mu g} / \mathbf{g} \text { tissue) }\end{array}$ & $\begin{array}{c}\text { Total Dose Rate } \\
(\mathbf{G y} / \mathbf{s})\end{array}$ & $\begin{array}{c}\text { Irradiation Time to Reach 50 } \\
\mathbf{G y} \\
\text { (seconds) }\end{array}$ & $\begin{array}{c}\text { Irradiation Time to Reach 50 } \\
\text { Gy } \\
\text { (minutes) }\end{array}$ \\
\hline 20 & $7.07593 \mathrm{E}-03$ & 7066.21 & 117.77 \\
25 & $7.07593 \mathrm{E}-03$ & 7066.21 & 117.77 \\
30 & $7.11830 \mathrm{E}-03$ & 7024.14 & 117.07 \\
50 & $7.20303 \mathrm{E}-03$ & 6941.52 & 115.69 \\
75 & $7.30895 \mathrm{E}-03$ & 6840.93 & 114.02 \\
100 & $7.41487 \mathrm{E}-03$ & 6743.21 & 112.39 \\
125 & $7.52078 \mathrm{E}-03$ & 6648.24 & 110.80 \\
150 & $7.62669 \mathrm{E}-03$ & 6555.92 & 109.27 \\
\hline
\end{tabular}


Table 7. In Vivo Measurements

\begin{tabular}{|c|c|c|c|c|}
\hline $\begin{array}{c}\text { Boron } \\
\text { Concentration } \\
(\mu \mathrm{g} / \mathrm{g} \text { tissue })\end{array}$ & Description & $\begin{array}{c}\text { Total Dose Rate } \\
(\mathrm{Gy} / \mathrm{s})\end{array}$ & $\begin{array}{c}\text { Irradiation Time to } \\
\text { Reach } 50 \text { Gy } \\
\text { (seconds) }\end{array}$ & $\begin{array}{c}\text { Irradiation Time to } \\
\text { Reach } 50 \text { Gy } \\
\text { (minutes) }\end{array}$ \\
\hline \multirow{4}{*}{20} & Normal Tissue & $2.98269 \mathrm{E}-03$ & \multirow{4}{*}{9814.98} & \multirow{4}{*}{163.58} \\
\hline & GTV & $5.09425 \mathrm{E}-03$ & & \\
\hline & CTV & $5.35544 \mathrm{E}-03$ & & \\
\hline & PTV & $5.21645 \mathrm{E}-03$ & & \\
\hline \multirow{4}{*}{25} & Normal Tissue & $2.98368 \mathrm{E}-03$ & \multirow{4}{*}{9766.79} & \multirow{4}{*}{162.78} \\
\hline & GTV & 5.11939E-03 & & \\
\hline & CTV & $5.36755 \mathrm{E}-03$ & & \\
\hline & PTV & 5.21894E-03 & & \\
\hline \multirow{4}{*}{30} & Normal Tissue & $2.98466 \mathrm{E}-03$ & \multirow{4}{*}{9719.07} & \multirow{4}{*}{161.98} \\
\hline & GTV & 5.14453E-03 & & \\
\hline & CTV & $5.37965 \mathrm{E}-03$ & & \\
\hline & PTV & $5.22142 \mathrm{E}-03$ & & \\
\hline \multirow{4}{*}{50} & Normal Tissue & 2.98862E-03 & \multirow{4}{*}{9532.74} & \multirow{4}{*}{158.88} \\
\hline & GTV & $5.24508 \mathrm{E}-03$ & & \\
\hline & CTV & $5.42808 \mathrm{E}-03$ & & \\
\hline & PTV & $5.23137 \mathrm{E}-03$ & & \\
\hline \multirow{4}{*}{75} & Normal Tissue & $2.99356 \mathrm{E}-03$ & \multirow{4}{*}{9309.62} & \multirow{4}{*}{155.16} \\
\hline & GTV & 5.37079E-03 & & \\
\hline & CTV & $5.48860 \mathrm{E}-03$ & & \\
\hline & PTV & $5.24380 \mathrm{E}-03$ & & \\
\hline \multirow{4}{*}{100} & Normal Tissue & $2.99851 \mathrm{E}-03$ & \multirow{4}{*}{9096.69} & \multirow{4}{*}{151.61} \\
\hline & GTV & $5.49650 \mathrm{E}-03$ & & \\
\hline & CTV & 5.54913E-03 & & \\
\hline & PTV & $5.25622 \mathrm{E}-03$ & & \\
\hline \multirow{8}{*}{125} & Normal Tissue & $3.00345 \mathrm{E}-03$ & \multirow{4}{*}{8893.26} & \multirow{4}{*}{148.22} \\
\hline & GTV & 5.62223E-03 & & \\
\hline & CTV & $5.60962 \mathrm{E}-03$ & & \\
\hline & PTV & 5.26864E-03 & & \\
\hline & Normal Tissue & 3.00839E-03 & \multirow{4}{*}{8698.77} & \multirow{4}{*}{144.98} \\
\hline & GTV & $5.74794 \mathrm{E}-03$ & & \\
\hline & CTV & $5.67014 \mathrm{E}-03$ & & \\
\hline & PTV & $5.28107 \mathrm{E}-03$ & & \\
\hline
\end{tabular}

\section{Irradiation Time vs Boron Concentration}

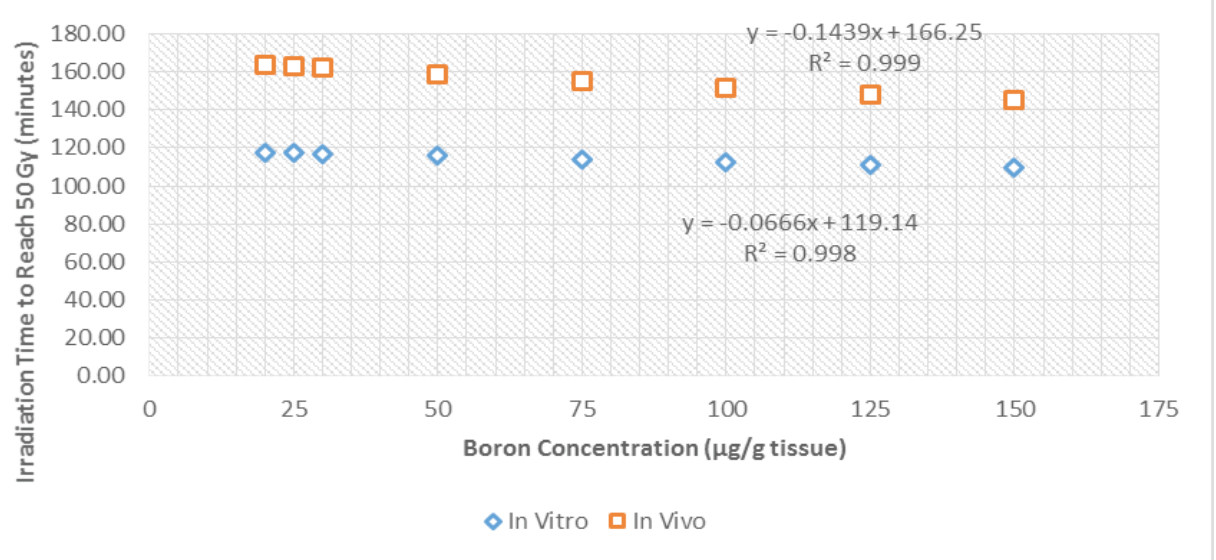

Figure 2. Graph of Irradiation Time vs Boron Concentration 
Adrian Tesalonika, Andang Widi Harto, Yohannes Sardjono, Isman Mulyadi Triatmoko, Dosimetry of in Vitro and in Vivo Trials in Thermal Column Kartini Reactor for Boron Neutron Capture Therapy (BNCT) Facility by Using MCNPX Simulator Code

To full fill those ideas, Indonesian governments should help researchers and policy makers develop more research and simulations related to development of BNCT in Indonesia.

\section{REFERENCES}

American Cancer Society. (2014). The Science Behind Radiation Therapy. Retrieved from http://www.cancer.org/acs/groups/cid/ documents/webcontent/003019-pdf.pdf

Andang Widi Harto. (n.d.). Metode Monte Carlo, kuliah tanggal 28 Agustus 2014. Yogyakarta: Jurusan Teknik Fisika, Universitas Gadjah Mada.

Bambang Hadi Santoso. (2014). Pemodelan Perisai Radiasi Fasilitas BNCT dengan Sumber Beamport Tembus Teras Reaktor Kartini Menggunakan MCNP5. Yogyakarta: Jurusan Teknik Fisika, Fakultas Teknik, Universitas Gadjah Mada.

D. Rorer, A. Wambersie, G. Whitmore, R. Zamenhof, V. Levin, P. Andreo, \& B. Dodd. (2001). Current Status of Neutron Capture Therapy. Vienna: International Atomic Energy Agency.

Denise B. Pelowitz. (2008). MCNPX User's Manual version 2.6.0.

Dwi Berlianti Siwi. (2013). Analisis Dosis di Organ Kritis Pada Terapi Glioblastioma dengan Boron Neutron Capture Therapy Menggunakan Metode Simulasi MCNP5. Yogyakarta: Departemen Teknik FIsika, Fakultas Teknik, Universitas Gadjah Mada.

Ferlay J, Soerjomataram I, Ervik M, Dikshit R, Eser S, Mathers C, \& et al. (2013). Cancer Incidence and Mortality Worldwide: IARC CancerBase No.11. GLOBOCAN 2012 v1.0. Lyon, France: International Agency for Research on Cancer.

Herman Cember, \& Tomas E. Johnson. (2009). Introduction to Health Physics (4th ed.).
New York: The McGraw-Hill Companies, Inc.

International Commission on Radiation Unit and Measurements. (1989). Report 44. USA.

Irhas. (2014). Dosimetri Boron Neutron Capture Therapy pada Kanker Hati (Hepatocellular Carcinoma) Menggunakan MCNP-code dengan Sumber Neutron dari Kolom Termal Reaktor Kartini. Yogyakarta: Departemen Teknik Fisika, Fakultas Teknik, Universitas Gadjah Mada.

M.Ilma Muslih Arrozaqi. (2014). Dasar-Dasar Pemrograman MCNPX. Yogyakarta: Pusat Sains dan Teknologi Akselerator Badan Tenaga Nuklir Nasional.

Mugi Wahidin, Rini Noviani, Sofia Hermawan, Vita Andriani, Ardi Ardian, \& Hernani Djarir. (2012). Population-Based Cancer Registration in Indonesia. Asian Pacific Journal of Cancer Prevention, 13.

Nicholas Tsoulfanidis. (1995). Measurement and Detection of Radiation. Washington, DC, United States of America: Taylor \& Francis.

Nina Fauziah. (2013). A Conceptual Design of Neutron Collimator in The Thermal Column of Kartini Research Reactor for Boron Neutron Capture Therapy. Yogyakarta, Indonesia: Departemen Teknik Fisika, Fakultas Teknik, Universitas Gadjah Mada.

Oxford Dictionaries. (n.d.). Oxford Dictionaries - in vitro. Retrieved September 15, 2015, from http:/www.oxforddictionaries.com/ definition/english/in-vitro

Oxford Dictionaries. (n.d.). Oxford Dictionaries - in vivo. Retrieved September 15, 2015, from http://www.oxforddictionaries.com/ definition/english/in-vivo?q=in+vivo

Ranti Warfi. (2015). Optimasi Kolimator Kolom Termal untuk Fasilitas Uji in vitro dan in 
vivo BNCT di Reaktor Kartini Menggunakan Simulator MCNP-X. Yogyakarta: Departemen Teknik Fisika, Fakultas Teknik, Universitas Gadjah Mada.

W. A. G. Sauerwein, A. Wittig, R. Moss, \& Y. Nakagawa. (2012). Neutron Capture
Therapy: Principles and Application. Berlin: Springer-Verlag.

World Health Organization. (2015, Februari). Cancer. Retrieved Juli 13, 2015, from http:// www.who.int/mediacentre/factsheets/fs297/ en/ 